Економічні науки: збірник наукових праиь Луиького національного технічного університету. - Серія "Регіональна економіка". - Випуск 15 (59). - Редкол.: відп. ред. д.е.н., професор Л.Л. Ковальська. - Луцьк: ІВВ Луиького НТУ, 2018. - 292 с.

УДК 332.14

Кондіус І.С., к.е.н., доцент

Луцький національний технічний університет

\title{
ДОСЛІДЖЕННЯ РИБНОГО ГОСПОДАРСТВА НА НАЦІОНАЛЬНОМУ ТА РЕГІОНАЛЬНОМУ РІВНЯХ
}

У статті представлені результати дослідження стану та основних перспектив розвитку риболовної галузі. За результатами дослідження встановлено, що рибна галузь, незважаючи на те, що Україна володіє достатнім ресурсним потенціалом для збільшення обсягів вирощування та вилову товарної риби, не забезпечує потреб споживачів продукцією 
Економічні науки: збірник наукових праиь Луиького національного технічного університету. - Серія "Регіональна економіка". - Випуск 15 (59). - Редкол.: відп. ред. д.е.н., професор Л.Л. Ковальська. - Луцьк: ІВВ Луиького НТУ, 2018. - 292 с.

вітчизняного виробництва. В статті запропоновані заходи, що сприятимуть розвитку виробництва продукції рибництва в Україні, підвищенню конкурентоспроможності рибних господарств та зниженню залежності від імпорту продовольчого сектору економіки.

Ключові слова: риба, риболовне господарство, ефективність, потенціал.

Kondius I.

\section{RESEARCH OF FISHING AGRICULTURE AT NATIONAL AND REGIONAL LEVELS}

The article presents the results of the study of the state and main perspectives of the development of the fishing industry. According to the results of the study, the fish industry, despite the fact that Ukraine has sufficient resources to increase the volume of production and catch of commercial fish, does not meet the needs of consumers by products of domestic production. The article proposes measures that will promote the development of fish production in Ukraine, increase the competitiveness of fish farms and reduce the dependence on imports of the food sector of the economy.

Keywords: fish, fishing, efficiency, potential.

Кондиус И.С.

\section{ИССЛЕДОВАНИЕ РЫБНОГО ХОЗЯЙСТВА НА НАЦИОНАЛЬНОМ И РЕГИОНАЛЬНОМ УРОВНЯХ}

В статье представлены результаты исследования состояния и основных перспектив развития рыболовной отрасли. По результатам исследования установлено, что рыбная отрасль, несмотря на то, что Украина обладает достаточным ресурсным потенциалом для увеличения объемов выращивания и вылова товарной рыбы, не обеспечивает потребностей потребителей продукцией отечественного производства. В статье предложены мероприятия, способствующие развитию производства продукции рыбоводства в Украине, повышению конкурентоспособности рыбных хозяйств и снижению зависимости от импорта продовольственного сектора экономики..

Ключевые слова: рыба, рыболовное хозяйство, эффективность, потенциал.

Постановка проблеми у загальному вигляді та іiї зв'язок з важливими науковими і практичними завданнями.

Сьогодні рибництву належить важлива роль у розв'язанні продовольчої проблеми. Внесок у гармонізацію і доступність харчування населення покликане здійснити рибне господарство. 

університету. - Серія "Регіональна економіка". - Випуск 15 (59). - Редкол.: відп. ред. д.е.н., професор Л.Л. Ковальська. - Луиьк: ІВВ Луиького НТУ, 2018. - 292 с.

Україна, поряд з усіма країнами світу, спрямовує свої зусилля на вирішення проблеми розширення асортименту рибної продукції, адже продукція рибної промисловості застосовується більш ніж в двадцяти галузях народного господарства. Обсяги біологічних ресурсів гідрофауни та гідрофлори, їх недостатне і не завжди раціональне використання $€$ переконливими аргументами значимості рибного господарства та перспективності його розвитку в сучасному глобалізованому світі.

Однак, незважаючи на важливість розвитку аквакультури, рівень забезпеченості рибною продукцією вітчизняного виробництва критично низький та не відповідає обгрунтованим нормам споживання. Відповідно набуває значної актуальності дослідження перспективних напрямів розвитку інтенсивного рибництва та реалізації економічного потенціалу галузі.

Аналіз останніх досліджень, у яких започатковано вирішення проблеми. Основні проблеми розвитку галузі рибництва в Україні досліджені у працях вітчизняних економістів: П.П. Борщевського [1], Н.М. Вдовенко [2], Ю.В. Кернасюка [3], Н.І. Смирнюка [4], С.В. Аверинцева [5], П.Т. Галасуна [6], А.І. Андрющенко [6], Р.А. Балтаджі [6], С. Пертенка [7], Б. Саксонова [8], В. Свинцова [9] та інших вчених. Однак для аквакультури України в останні роки характерні кризові явища, які обумовлені різким спадом вирощування та вилову риби, зростанням реалізаційних цін та значним скороченням фонду споживання. Вирішення зазначених проблемних питань потребує нового підходу до визначення основних перспективних напрямів розвитку аквакультури в Україні.

Цілі статті. Дослідження фактичного стану та обгрунтування перспективних напрямів розвитку аквакультури в Україні.

Виклад основного матеріалу дослідження 3 повним обгрунтуванням отриманих наукових результатів. Рибному господарству традиційно належить важлива роль у забезпеченні продовольчої безпеки в багатьох країнах світу й підтриманні зайнятості населення та його добробуту, тоді як сам рибний 
Економічні науки: збірник наукових праиь Луиького національного технічного університету. - Серія "Регіональна економіка". - Випуск 15 (59). - Редкол.: відп. ред. д.е.н., професор Л.Л. Ковальська. - Луцьк: ІВВ Луиького НТУ, 2018. - 292 с.

промисел формує досить вагому частку грошових надходжень і доходів, у тому числі податків та зборів. Останніми роками у зв'язку зі значним зменшенням у світовому океані запасів риби, а відповідно й обсягів їі вилову, все більшого поширення набуває розвиток різних форм аквакультури. Рибництво $\epsilon$ однією 3 небагатьох галузей вітчизняної економіки, яка забезпечує не лише продовольчу безпеку держави, але й дозволяє диверсифікувати агробізнес і підвищити дохідність його ведення при порівняно незначних початкових інвестиціях та гарантованому ринку збуту [3]. На відміну від тваринництва, рибодобувна промисловість, у силу іiі специфіки, могла б швидко і в значних обсягах збільшити продовольчі ресурси країни в результаті зростання чисельності й удосконалення матеріально-технічної бази рибодобувної галузі [1]. Законом України «Про аквакультуру» встановлено, що аквакультура сільськогосподарська діяльність із штучного розведення, утримання та вирощування об'єктів аквакультури у повністю або частково контрольованих умовах для одержання сільськогосподарської продукції (продукції аквакультури) та іiі реалізації, виробництва кормів, відтворення біоресурсів, ведення селекційно-племінної роботи, інтродукції, переселення, акліматизації та реакліматизації гідробіонтів, поповнення запасів водних біоресурсів, збереження їх біорізноманіття, а також надання рекреаційних послуг. Інтенсивна форма аквакультури розглядається, як організаційно-технологічна форма рибогосподарської діяльності у сфері аквакультури, за якої вирощування об'єктів аквакультури здійснюється 3 ущільнених посадок 3 інтенсивною штучною годівлею комбікормами, збалансованими за складом відповідно до біологічних потреб конкретних гідробіонтів, та іншими кормами 3 високою поживністю. За даними державного комітету статистики України, за 2017 рік було добуто всього 92,65 тис. т водних біоресурсів, 3 яких 45,5\% у внутрішніх водоймах (табл. 2.3). Обсяг вилову риби у внутрішніх водоймах у порівнянні з минулим роком збільшився на $3,5 \%$. Зокрема, у 2017 р. в ставах було виловлено риби на 12,2\% менше ніж у 
Економічні науки: збірник наукових праџь Луцького національного технічного університету. - Серія "Регіональна економіка". - Випуск 15 (59). - Редкол.: відп. ред. д.е.н., професор Л.Л. Ковальська. - Луцьк: ІВВ Луиького НТУ, 2018. - 292 с.

2014 р. Із втратою частини морського риболовецького флоту у 2013 р., рибний промисел в економічних зонах інших держав скоротився вдвічі.

Таблиця 1

Добування риби та інших водних біоресурсів у 2017 р.*

\begin{tabular}{|l|c|c|c|c|}
\hline \multirow{2}{*}{} & \multicolumn{2}{|c|}{ Обсяг добування } & \multicolumn{2}{c|}{$\begin{array}{c}\text { Структура } \\
\text { добування, у \% до } \\
\text { загального обсягу }\end{array}$} \\
\cline { 2 - 5 } & тонн & $\begin{array}{c}2017 \text { у \% } \\
\text { до 206 }\end{array}$ & 2017 & 2016 \\
\hline $\begin{array}{l}\text { Добуто водних біоресурсів - } \\
\text { усього у тому числі }\end{array}$ & 92645 & 104,8 & 100 & 100 \\
\hline у т. ч. риби & 81875 & 104,3 & 88,4 & 88,7 \\
\hline у внутрішніх водних об'єктах & 42176 & 103,5 & 45,5 & 46,1 \\
\hline $\begin{array}{l}\text { у виключній (морській) } \\
\text { економічній зоні України }\end{array}$ & 42520 & 105,4 & 45,9 & 45,6 \\
\hline
\end{tabular}

*Джерело: складено на основі [3]

Річний фонд споживання риби та рибних продуктів в Україні знизився за 2010 - 2017 рр. майже на 126 тис. т. (рис.1).

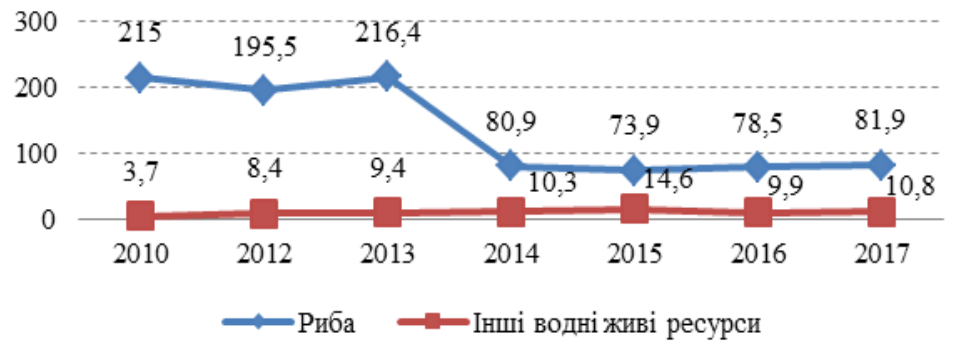

Рис. 1. Фонд споживання риби та рибних продуктів в Україні, тис.т.*

*Джерело: складено на основі (Добування водних біоресурсів за 2017 рік :

Статистичний бюлетень)

Так, у 2015 р. рівень споживання риби на одну особу в рік склав всього 8,6 кг, це на 22,5\% менше ніж у 2014 р., що зумовлено низькою купівельною спроможністю населення через 

університету. - Серія "Регіональна економіка". - Випуск 15 (59). - Редкол.: відп. ред. д.е.н., професор Л.Л. Ковальська. - Луиьк: ІВВ Луиького НТУ, 2018. - 292 с.

зростання цін на рибу та падіння реальних доходів більшості громадян держави. За два останні роки цей показник зріс. Так, у 2016 році рівень споживання риби на одну особу в рік склав 9,6 кг, що на 11,6\% більше ніж у 2015 р., а у 2017 році рівень споживання риби на одну особу в рік склав 10,5 кг, що на 9,4\% більше ніж у 2016 p.

Кризовий стан рибної галузі зумовлений, насамперед, швидкими темпами морального та фізичного зношення основних фондів підприємств, погіршенням технічного стану обладнання на рибопереробних підприємствах, модернізація якого відбувається дуже низькими темпами, використанням застарілих технологій, значним дефіцитом потужностей базової переробки риби, що в свою чергу призводить до недостатнього використання сировини, погіршення якості рибної продукції, яка не завжди відповідає міжнародним стандартам, недостатнього використання відходів основного виробництва.

Україна володіє значним потенціалом розвитку аквакультури, який недооцінений та нереалізований на хвилі стагнаційних процесів, що відбулися в економіці. У структурі видобутку водних біоресурсів 88,3\% - це риба, решта ракоподібні та молюски. Понад 50\% всього обсягу добутих водних біоресурсів припадає на три області - Запорізьку, Миколаївську та Одеську. Найменш розвинений риболовецький промисел у західних та північних областях, де відсутні відповідні природні умови в якості доступу до великих водних об'єктів (морів, великих річок, водосховищ, озер), які $є$ у південних та центральних областях (рис. 2). В Україні частка обсягу вилову прісноводної та морської риби у 2017 р. становили 52 та $48 \%$ відповідно. 
Економічні науки: збірник наукових праџь Луцьького національного технічного університету. - Серія "Регіональна економіка". - Випуск 15 (59). - Редкол.: відп. ред. д.е.н., професор Л.Л. Ковальська. - Луцьк: ІВВ Луиького НТУ, 2018. - 292 с.

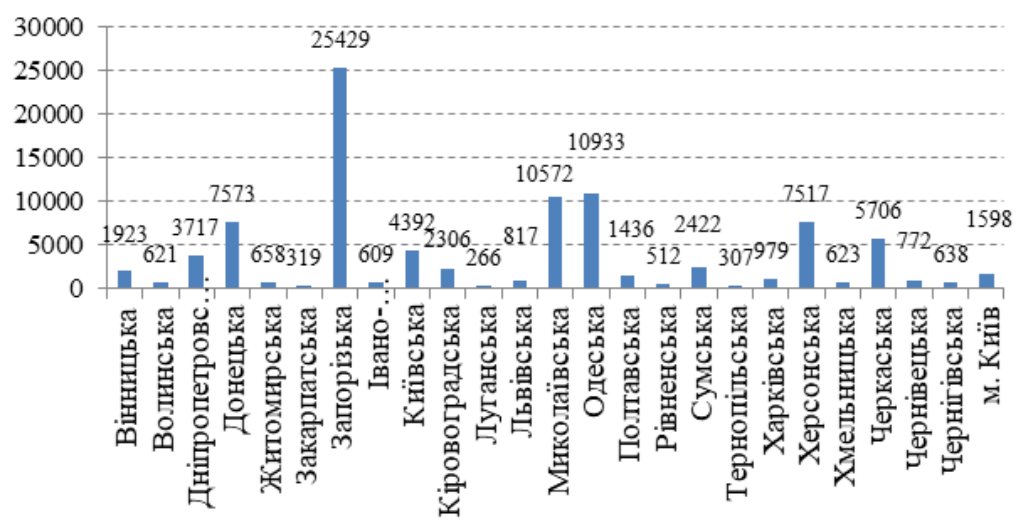

Рис. 2. Добування водних біоресурсів за регіонами у 2017 р. (т)* *Джерело: складено на основі (Добування водних біоресурсів за 2017 рік : Статистичний бюлетень)

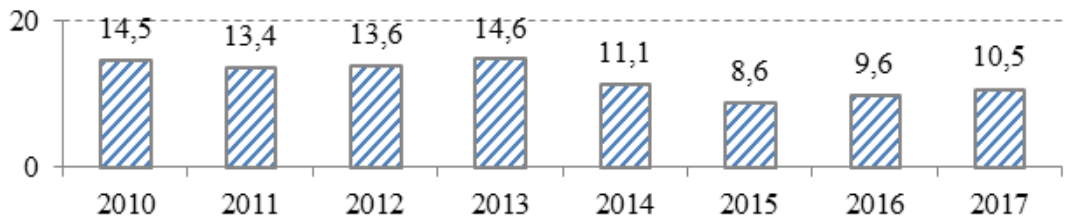

Рис. 3. Споживання риби та рибопродуктів на 1 особу за 2017 рік, кг.*

*Джерело: складено на основі (Добування водних біоресурсів за 2017 рік: Статистичний бюлетень)

Для забезпечення внутрішнім виловом риби споживчих потреб населення України, необхідно збільшити обсяги вирощування та вилову у 2 рази, що неможливо без раціонального використання об' єктів водного фонду та розвитку на цій основі високотехнологічної аквакультури. Понад $80 \%$ від усієї морської риби, яка виловлена риболовецькими підприємствами, припадає на бичка. Структура вилову прісноводної риби наведена на рис. 4. 
Економічні науки: збірник наукових праиь Луиького національного технічного університету. - Серія "Регіональна економіка". - Випуск 15 (59). - Редкол.: відп. ред. д.е.н., професор Л.Л. Ковальська. - Луцьк: ІВВ Луиького НТУ, 2018. - 292 с.

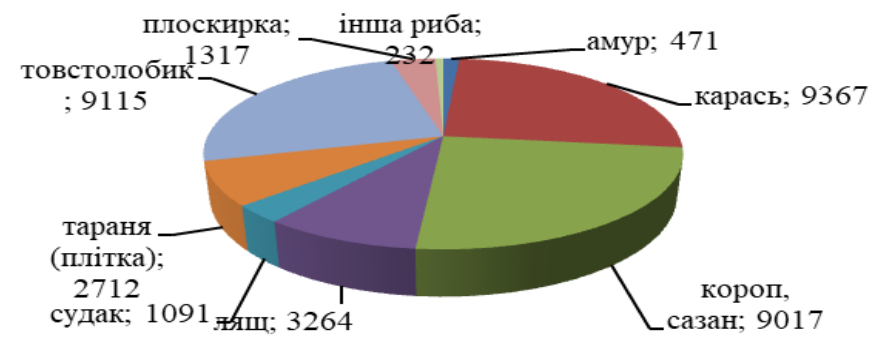

Рис. 4. Структура вилову прісноводної риби за видами у 2017 р. У 2017 р. відбулося збільшення обсягу вилову прісноводної риби на 8\%. При цьому, найбільшу частку від обсягу вилову становив товстолобик, що є цілком характерним явищем для випасної аквакультури, яка стала переважати у значній частині рибогосподарських підприємств України. Коропа у 2017 р. виловлено всього 9 тис. т, що становить 28\% від валового обсягу добутої прісноводної риби. Враховуючи інфляційне зростання реалізаційних цін на рибу, вартість виловленої товарної прісноводної риби зросла на третину та становила 603 млн. грн., 3 яких 45\% припадає на коропа.

Ринок рибної продукції в Україні на 60 - 70\% формується на основі імпортної сировини, що негативно впливає на продовольчу безпеку. Також слід зазначити, що проблема криється в структурі споживання риби населенням країни, у якій частка прісноводних риб, що вирощуються вітчизняними господарствами не перевищує $12 \%$, а морської не покривається повною мірою виловом риболовецьким флотом у морських економічних зонах України та інших держав, тому імпортується для задоволення внутрішнього попиту. Традиційне формування вітчизняного ринку рибної продукції на основі імпортної сировини $є$ відображенням споживчих звичок українських покупців, що обходиться щорічно у 290 млн. дол. США негативного торгівельного сальдо для економіки України лише за даною товарною групою. Необхідно впроваджувати активну інформаційну політику, націлену на зміну споживчих уподобань покупців з метою зміни структури споживання риби на користь прісноводних видів, які вирощуються та виловлюються 
Економічні науки: збірник наукових праиь Луиького національного технічного університету. - Серія "Регіональна економіка". - Випуск 15 (59). - Редкол.: відп. ред. д.е.н., професор Л.Л. Ковальська. - Луцьк: ІВВ Луцького НТУ, 2018. - 292 с.

вітчизняними рибогосподарськими підприємствами. Підвищення попиту на такі важливі у рибному промислі види риб як короп, товстолобик, білий амур, лин, лящ тощо, сприятиме активному розвитку рибництва у внутрішніх водоймах та частково скоротить обсяги імпорту. Забезпечення зростання обсягів вирощування та вилову риб повинно грунтуватися на впровадженні комплексної державної програми розвитку аквакультури із залученням усіх наявних водних, матеріально-технічних та сировинних ресурсів.

Рибна галузь України перебуває у кризовому стані. За 2013- 2017 рр. обсяг вилову риби скоротився вдвічі. Вітчизняна аквакультура забезпечує внутрішні споживчі потреби у рибі лише на 20\%, або 10 кг у розрахунку на одного жителя в рік. Відповідно близько 300 тис. т. імпортної рибної продукції на суму 290 млн. дол. США у 2017 р. покрили нестачу власного виробництва. 3 метою сприяння розвитку інтенсивного рибництва в Україні необхідно реалізувати комплекс заходів, зокрема: відновлення ресурсного та виробничого потенціалу рибної галузі, шляхом створення сприятливого економічного середовища для залучення інвестицій у впровадження інноваційних технологій інтенсивної аквакультури ставового, садкового, річкового та басейнового типів; розвитку збутової інфраструктури; забезпеченню пільгового цільового кредитування підприємств рибної галузі на оновлення основних виробничих засобів та відновлення водних об'єктів, придатних для вирощування гідробіонтів; встановлення інтеграційних процесів між господарствами рибної галузі та господарюючими суб'єктами галузей рослинництва, тваринництва та підприємствами харчової промисловості, які сприяють розвитку аквакультури в Україні.

Діюча Державна цільова економічна програма розвитку рибного господарства на 2012-2016 роки не досягла визначених критеріїв іï ефективності та головної мети, а саме щодо створення сприятливих умов для забезпечення розвитку рибного господарства та його конкурентоспроможності на внутрішньому i зовнішньому ринках, для задоволення потреби населення 
Економічні науки: збірник наукових праиь Луиького національного технічного університету. - Серія "Регіональна економіка". - Випуск 15 (59). - Редкол.: відп. ред. д.е.н., професор Л.Л. Ковальська. - Луиьк: ІВВ Луиького НТУ, 2018. - 292 с.

України у рибній продукції відповідно до науково обгрунтованих норм споживання, які становлять 20 кг риби на одну особу за рік. Відповідно, значної актуальності набувають подальші дослідження основних чинників розвитку рибогосподарських підприємств 3 метою економічного обгрунтування впровадження заходів та пропозицій, які дозволять вивести 3 кризи українську аквакультуру та сприятимуть їі інтенсивному зростанню.

Висновки. Майже повна відсутність фінансування Державної цільової економічної програми розвитку рибного господарства на 2015-2020 роки, основною метою якої $\epsilon$ забезпечення розвитку рибного господарства для забезпечення населення України рибою та гарантування продовольчої безпеки, що унеможливлює виконання ії ключових завдань i заходів. Необхідне сприяння Мінагрополітики України щодо збільшення видатків на розвиток галузі та забезпечення фінансування заходів Державної цільової економічної програми розвитку рибного господарства на 2015-2020 роки.

Досягнення рівня належного фінансування для проведення гармонізації стандартів 3 виробництва рибної продукції до вимог Європейського Союзу та впровадження передових технологій переробки риби.

3 метою забезпечення прибутків в рибному господарстві, створення необхідних умов для залучення інвестицій необхідно продовжити роботу щодо: внесення змін у чинне законодавство 3 метою спрощення процедури надання водних об’єктів у користування на умовах оренди для цілей аквакультури; зниження податкового та адміністративного навантаження на суб'єкти господарювання, що займаються аквакультурою та рибним промислом для здешевлення риби і рибної продукції; створення необхідних умов для отримання рибницькими i рибальськими підприємствами кредитів у фінансових установах; забезпечення на державному рівні здешевлення кредитів рибницьким та рибальським підприємствам; підготовка 
Економічні науки: збірник наукових праџь Луцького національного технічного університету. - Серія "Регіональна економіка". - Випуск 15 (59). - Редкол.: відп. ред. д.е.н., професор Л.Л. Ковальська. - Луцьк: ІВВ Луцького НТУ, 2018. - 292 с.

необхідної нормативної бази для здійснення морської аквакультури.

Необхідність запровадження національної системи і механізму функціонування сертифікату походження риби, що підтверджує законність походження вилову водних біоресурсів iз середовища їх існування при здійсненні торговельних операцій продукцією 3 водних біоресурсів для боротьби 3 незаконним рибальством і створення належної інфраструктури та електронних рибних бірж.

1. Borshchevskyi P.P., Stasyshen M.S., Alesina N.V. (2003). Stratehichni problemy rozvytku rybnoho hospodarstva Ukrainy. Stratehiia rozvytku Ukrainy (ekonomika, sotsiolohiia, pravo): nauk. zhur. K.: NAU. 1-2, 371-387.

2. Vdovenko N.M. (2010). Suchasnyi stan ta napriamy rozvytku rybnoho hospodarstva v Ukraini. Vdovenko. Ekonomika APK. 3, 15-20 (in Ukrainian).

3. Kernasiuk Iu.V. (2014). Rybnytstvo: potentsial ye! Ahrobiznes. 11(282) [Elektronnyi resurs]. - Rezhym dostupu: http://www.agro-business.com.ua/ agrobusiness/archive.html?func=show_edition\&id=107 (in Ukrainian).

4. Smyrniuk N.I., Buriak I.V., Tovstenko L.V., Chernik V.V. (2009). Suchasnyi stan vyrobnytstva rybnoi produktsii v Ukraini. Rybohospodarska nauka Ukrainy. 4, 109-116 (in Ukrainian).

5. Аверинцев С.В. Курс зоологии. Т. 2. Хордовые: учеб. для педагогов и учителей ин-тов / С.В. Аверинцев. - М.: Просвещение, 1954. - 456 с.

6. Галасун, П.Т. Інтенсифікація рибництва / П.Т. Галасун, А.І. Андрющенко, Р.А. Балтаджі. - К.: Урожай, 1990. - 112 с.

7. Петренко С. Привереда карась и голавль «в подкидного» / Рыболовный мир. - 2006. - № 4. - С. 50-55.

8. Саксонов Б. Ловля окуня / Рыболовный мир. - 2005. № 4. С. 24-26.

C. $53-56$.

9. Свинцов В. На карпа - с фидером / Рыболов-Украина. - 2004. № 4. 